\title{
BIOGAS DIGESTER WITH SIMPLE SOLAR HEATER
}

\author{
KH. S. KARIMOV ${ }^{1,2}$ AND MUHAMMAD ABID ${ }^{1}$ \\ ${ }^{1}$ GIK Institute of Engineering Sciences and Technology, Topi, Pakistan. \\ ${ }^{2}$ Physical Technical Institute of Academy of Sciences, Tajikistan.
}

khasan@giki.edu.pk,abid@giki.edu.pk

\begin{abstract}
In this research work, the design, fabrication and investigation of a biogas digester with simple solar heater are presented. For the solar heater, a built-in reverse absorber type heater was used. The maximum temperature $\left(50^{\circ} \mathrm{C}\right)$ inside the methane tank was taken as a main parameter for the design of the digester. Then, the energy balance equation for the case of a static mass of fluid being heated was used to model the process. The parameters of thermal insulation of the methane tank were also included in the calculations. The biogas digester consisted of a methane tank with built-in solar reverse absorber heater to harness the radiant solar energy for heating the slurry comprising of different organic wastes (dung, sewage, food wastes etc.). The methane tank was initially filled to $70 \%$ of its volume with organic wastes from the GIK institute's sewage. The remaining volume was filled with sewage and cow dung from other sources. During a three month period (October-December, 2009) and another two month period (February-March, 2010), the digester was investigated. The effects of solar radiation on the absorber, the slurry's temperature, and the ambient temperature were all measured during these investigations. It was found that using sewage only and sewage with cow dung in the slurry resulted in retention times of four and two weeks, respectively. The corresponding biogas produced was $0.4 \mathrm{~m}^{3}$ and $8.0 \mathrm{~m}^{3}$, respectively. Finally, this paper also elaborates on the upgradation of biogas through the removal of carbon dioxide, hydrogen sulphide and water vapour, and also the process of conversion of biogas energy into electric power
\end{abstract}

ABSTRAK: Kajian ini membentangkan rekabentuk, fabrikasi dan penyelidikan tentang pencerna biogas dengan pemanas solar ringkas. Sebagai pemanas solar, ia dilengkapkan dengan penyerap pemanas beralik. Suhu maksimum $\left(50^{\circ} \mathrm{C}\right)$ di dalam tangki metana telah diambil sebagai parameter utama rekabentuk pencerna. Dengan menggunakan persamaan tenaga seimbang untuk jisim statik cecair yang dipanaskan; parameter penebat haba tangki metana telah dikira. Pencerna biogas terdiri dari tangki metana yang dilengkapkan dengan penyerap pemanas beralik untuk menggunakan tenaga solar bagi memanaskan sluri yang disediakan dari bahan buangan organik yang berbeza (najis, sampah, sisa makanan,etc). Tangki metana telah diisi sehingga $70 \%$ isipadu buangan oraganik dari institut GIK, pertamanya adalah sampah dan keduanya adalah najis lembu. Pencerna telah dikaji bagi tempoh tiga bulan (Oktober-Disember, 2009) dan dua bulan (FebruariMac, 2010). Kejadian radiasi solar terhadap penyerap, suhu sluri dan suhu ambien telah diukur. Didapati suhu penahanan adalah empat minggu dan dua minggu masing-masing dengan menggunakan sampah sahaja dan sampah dengan najis lembu, dan kuantiti biogas dihasilkan adalah masing-masing $0.4 \mathrm{~m}^{3}$ and $8.0 \mathrm{~m}^{3}$. Sebagai tambahan, skema peningkatan biogas untuk peranjakan karbon dioksida, hidrogen sulfida dan wap air dari biogas dan penukaran tenaga biogas kepada tenaga elektrik juga dibincangkan.

KEYWORDS: solar biogas; digester; methane tank; reverse absorber; built-in heater; solar energy 


\section{INTRODUCTION}

Though solar energy represents practically an inexhaustible source and could satisfy energy needs of all of the population of the world for many centuries, its direct application is linked with great difficulties. Another perspective is the utilization of solar energy peserved in the biomass as a result of photosynthetic process. This has received considerable attention in industrially developed as well as in the developing countries [1]. In addition, environmental agencies demand strengthening of attention to modern ways of processing of organic wastes to control problems of disinfection from the utilization of huge mass of dung of cattle-breeding farms. A recent trend in the power industry is the establishment of small-scale biogas plants, satisfying the needs of one or several families living in the countryside.

Biogas as a source of renewable energy is produced by biotechnology and used widely on a residential scale [1-12]. The biogas was produced for the very first time in 1814 by Davy from organic wastes. In 1900 production of biogas was started in Bombay (India). Biogas consists of 55-70\% methane $\left(\mathrm{CH}_{4}\right)$ and around of $27-44 \%$ carbon dioxide $\left(\mathrm{CO}_{2}\right)$ and less than $1 \% \mathrm{H}_{2}$ and $\mathrm{H}_{2} \mathrm{~S}$. At present biogas is used widely in some countries for lighting, machines, and vehicles, generators, cooking and heating. Biogas generation is suitable for small to large scale operation and at present is realized in a number of developed and developing countries including USA, Hungary, China, India etc. Since 1990s biogas projects construction in China has developed steadily by the end of 1998, there were altogether 6.88 million household biogas digesters [3]. In Russia biogas digesters are used for processing of hard dung into biogas. Over the last few years the very first biogas digesters were constructed in Tajikistan as well $[3,7]$ and it was found that the digesters can work with sufficiently high efficiency in mountain areas as well.

The biogas yield rate increases by about two times if the temperature increases by $5^{\circ} \mathrm{C}$. In colder climates the process of digestion goes up at heating up to $35^{\circ} \mathrm{C}$. For heating of biomaterials, solar energy is used in some digesters of laboratory (a bottle-type where a bioreactor has small volume) [3] or industrial type [8]. There are two methods of heating the digester by solar energy i.e. passive and active [5]. In the case of passive heating, for example, the digester's body can absorb the solar energy as a receiver through a lid or dome. If an active method is used the digesters consist of two basic parts: solar collector and bioreactor (methane tank) connected through pipes, heat exchanger and pump. In the whole, this system is more complicated and expensive. The laboratory type biogas digester with built-in solar collector and air heat exchanger, where natural convection was realized, had some advantages as compared to the conventional digester due to the shorter retention time (on 15\%) and larger amount of produced biogas (in 20\%) [7]. A reverse absorber heater is a new type of solar air collector where the convective and radiative heat losses are reduced. In this paper, design and fabrication of a biogas digester with simple solar heater (built-in solar reverse absorber heater) is discussed. This makes the system cheaper, more compact and reliable in its operation.

\section{DESIGN AND FABRICATION OF THE BIOGAS DIGESTER}

The biogas digester consists of a methane tank with built-in solar reverse absorber heater (RAH) to utilize solar energy for the heating of the slurry prepared from the different organic wastes such as dung, sewage, food wastes etc. and is shown in Fig.1a and Fig.1b. The digester is a laboratory (or domestic) type and consists of vertical axes cylindrical plastic methane tank of size $0.98 \mathrm{~m}$ in diameter; $1.05 \mathrm{~m}$ in height and $0.8 \mathrm{~m}^{3}$ in volume with a solar reverse absorber heater installed under the methane tank. The methane tank is installed on a pyramidal support. The outer surface of the methane tank was 
covered by thermo insulated material and aluminum foil. The metallic absorber's surface was blackened and made rough, firstly to increase absorption of solar irradiation from outside and secondly to increase area of the surface from the inside accordingly to the increase in the heat transfer from absorber to slurry. The absorber's area is $80 \%$ of the methane tank's bottom area. The absorber's shape was made circular. The inlet and outlet serve to load methane tank by slurry and release by tap respectively.

The solar RAH (Fig.1a) consists of horizontal axes cylindrical reflecting mirror and horizontal glass cover. Between horizontal glass cover and absorber there is an air gap of $20 \mathrm{~mm}$. A horizontal absorber is a common element of the methane tank and solar reverse heater. The cylindrical reflector was used with radius of $0.9 \mathrm{~m}$ and glazing size of $0.9 \times 0.7 \mathrm{~m}^{2}$. The angle between the inclined glass cover and horizontal plane was $45^{\circ}$, which is equal to the sum of latitude of location $\left(34^{\circ}\right)$ and half of solar declination angle $\left(11^{\circ}\right)$. The reflecting mirror as shown in Fig. 2 consists of the plane mirror (aluminum foil) strips pasted on plastic sheet. The size of every mirror strip was $0.1 \mathrm{~m} \times 1 \mathrm{~m}$. The sides of the cylinder have the same structure as the reflecting mirror: plane mirror, plastic sheet and plane metallic sheet. Figure 3 shows the fabricated solar biogas digester with flexible gas-holder whereas Fig. 4 shows a solar reflector.

\section{EXPERIMENTAL SETUP}

The methane tank was installed facing south at noon (12:00 p.m.) and filled up to $70 \%$ volume by organic wastes of the GIK institute sewage, firstly, and secondly, by sewage (50\%) and cow dung (25\% and $25 \%$ water) as well. In the case of use of cow dung only, the slurry is prepared with $50 \%$ of fresh dung and $50 \%$ of water. Solar beams penetrating through the inclined glass cover $\{14\}$ depicted in Fig. 1 are reflected from the reflector, penetrate the horizontal glass cover and are absorbed by the absorber which transfers heat to the slurry.

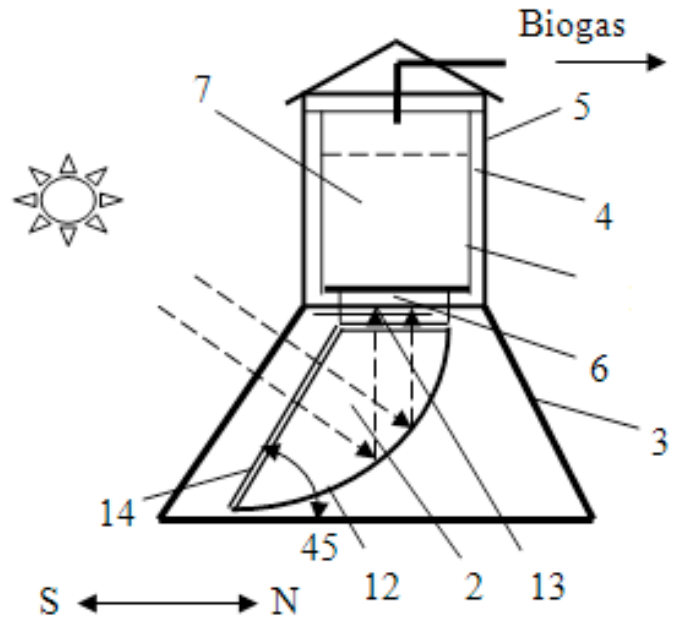

(a)

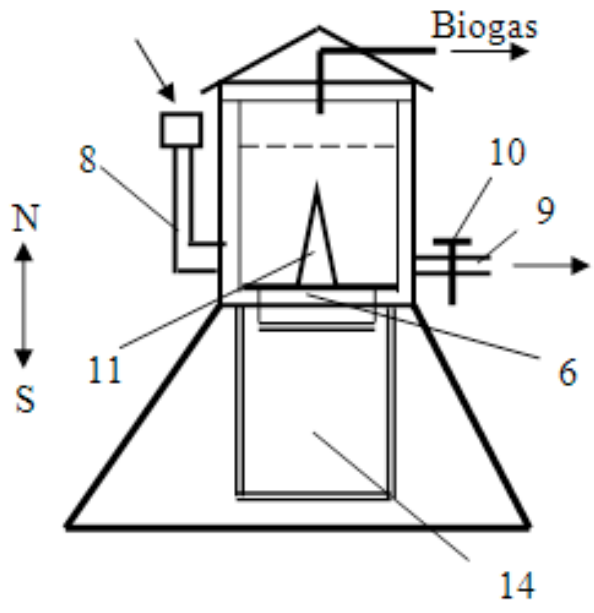

(b)

Fig. 1: The biogas digester with built-in solar reverse absorber heater: cylindrical plastic methane tank $\{1\}$, a reverse absorber heater $\{2\}$, a pyramidal support $\{3\}$. Thermo insulating material $\{4\}$, aluminum foil $\{5\}$, metallic absorber $\{6\}$, slurry $\{7\}$, inlet $\{8\}$, outlet $\{9\}$, tap $\{10\}$, partition $\{11\}$, horizontal axes, cylindrical reflecting mirror $\{12\}$, horizontal glass cover $\{13\}$, and inclined glass cover $\{14\}$. 


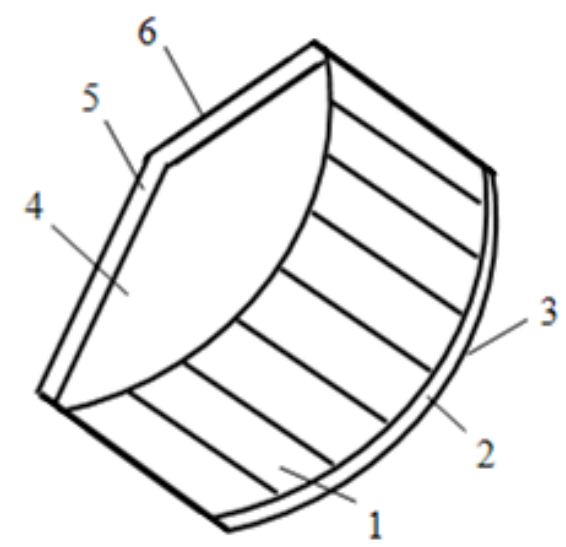

Fig. 2: The cylindrical reflecting mirror of the solar reverse absorber heater: the plane mirror strips $\{1\}$, the plastic sheet $\{2\}$, the cylindrical metallic ground $\{3\}$, the plane mirror $\{4\}$, plastic sheet $\{5\}$ and plane metallic sheet $\{6\}$.

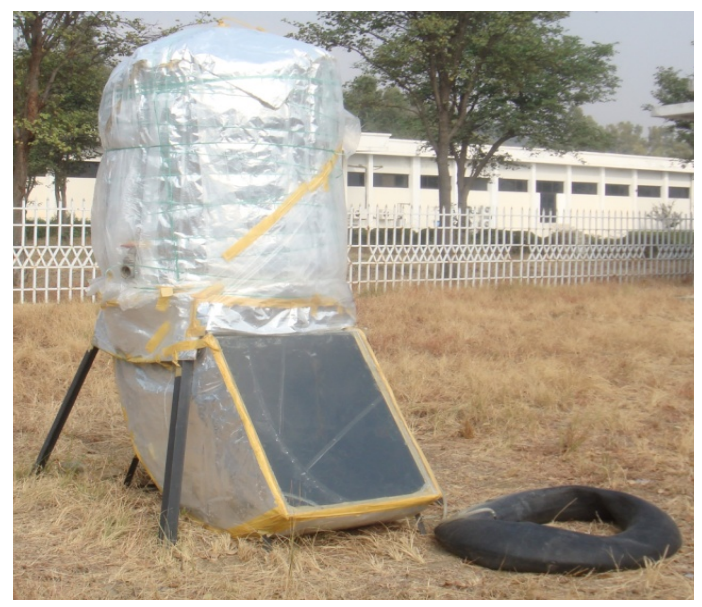

Fig. 3: Fabricated solar biogas digester with flexible gas-holder.

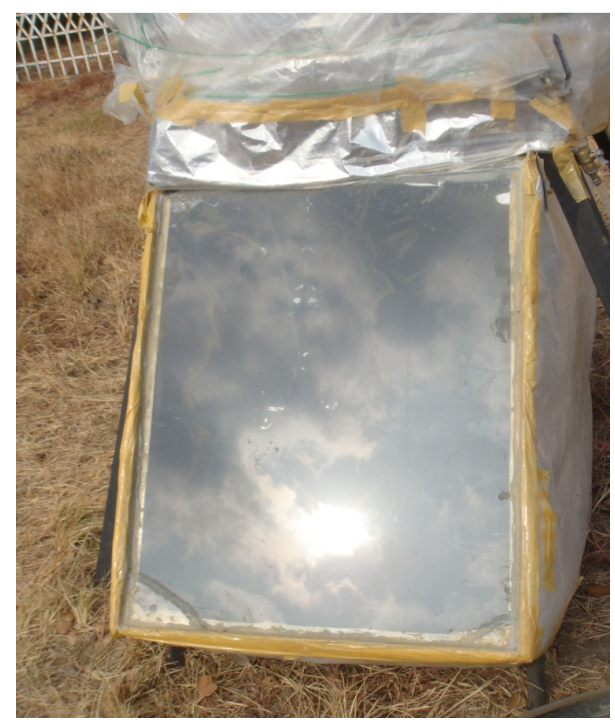

Fig. 4: Solar reflector. 
Ambient temperature, temperature of slurry and solar irradience was controled by semiconductor sensors connected to meters. Retention time $\left(t_{r}\right)$ was almost 18-22 days on an average. Experimental data was processed by the statistical approach described in [13]. During two minutes five measurements of solar irradiance and temperatures were recorded. Standard errors of the mean was $\pm 2 \mathrm{~mW} / \mathrm{sq} . \mathrm{cm}$ and $\pm 1^{\circ} \mathrm{C}$.

\section{RESULTS AND DISCUSSION}

The optimal temperature for psychrophilic, mesophilic and thermophilic bacteria growth, activity and biogas production is approximately $20^{\circ} \mathrm{C}, 35^{\circ} \mathrm{C}$ and $55^{\circ} \mathrm{C}$ respectively [8]. In the winter period, the average temperature in the biogas digester is usually lower and this condition decreases the rate of biogas production but increases the retention period. For analysis of the heating of the slurry by solar energy in the biogas production process the energy balance equation for the case of a static mass of fluid (the slurry's properties is considered as water properties) being heated may be used [3,8]:

$$
m c \frac{d T_{f}}{d t}=\alpha \tau A G-\frac{\left(T_{f}-T_{a}\right)}{R}
$$

where $m$ is mass of slurry, $c$ is specific heat capacity, $T_{f}$ is temperature of the slurry, $\alpha$ is absorptance of the absorber, $\tau$ is transmittance of the glass, $A$ is the exposed area of the absorber, $G$ is the global irradiance on the inclined glass cover, $T_{a}$ is ambient temperature and $R$ is thermal resistance to heat loss from absorber-slurry system to the outside environment. The thermal resistance $R$ reflects all heat losses due to the thermal conductance of insulating layer of the methane tank, convection and radiation from the surface of methane tank, evaporation of the slurry inside of the methane tank (evaporated water partly condensed after releasing its latent heat and partly is moved by biogas), and by reverse absorber heater (RAH). Since convection and radiation losses inside the RAH are minimized they may be neglected. Thus it may be assumed that mainly heat losses are due to methane tank's thermal insulator. Taking as a main parameter the maximum temperature of slurry inside of the methane tank to be $50^{\circ} \mathrm{C}$ that is close to thermophilic bacterias' growth and activity, using Eq.(1), the thermal resistance can be determined to be $R=0.33 \mathrm{~K} / W$, for the case when $\alpha=0.9, \tau=0.81$, for two glass layers of $A=$ $0.5 \mathrm{~m}^{2}, G=250 \mathrm{~W} / \mathrm{m}^{2}$, at the mean annual irradiance, and $T_{a}=20^{\circ} \mathrm{C}$ and taking into account the maximum temperature of the slurry $d T_{f} / d t=0$. Thermal resistance $(R)$ of the heat conductance given in [8] is as;

$$
R=\Delta x / k A_{m}
$$

where $k$ is thermal conductivity, $A_{m}$ is the area of the side surface and lid of the methane tank. Equation (2) can be used to determine the thickness of thermo insulating material $(\Delta x)$. The thickness of thermo insulating material would be equal to $10 \mathrm{~cm}$ if a thermo insulating material such as glass wool be used. Figure 5 shows solar irradiance, slurry's temperature and ambient temperature-time relationships obtained for one day in October, 2009 (Fig.5a) and March, 2010 (Fig.5b). It is seen that initially $T_{a}>T_{f}$ but starting from noon, where solar irradiance is the maximum, the slurry temperature prevails over the ambient temperature. 


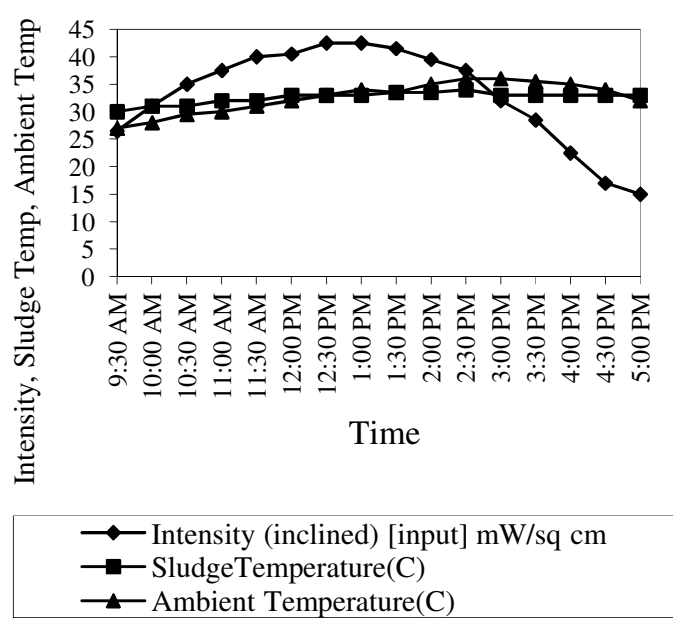

(a)

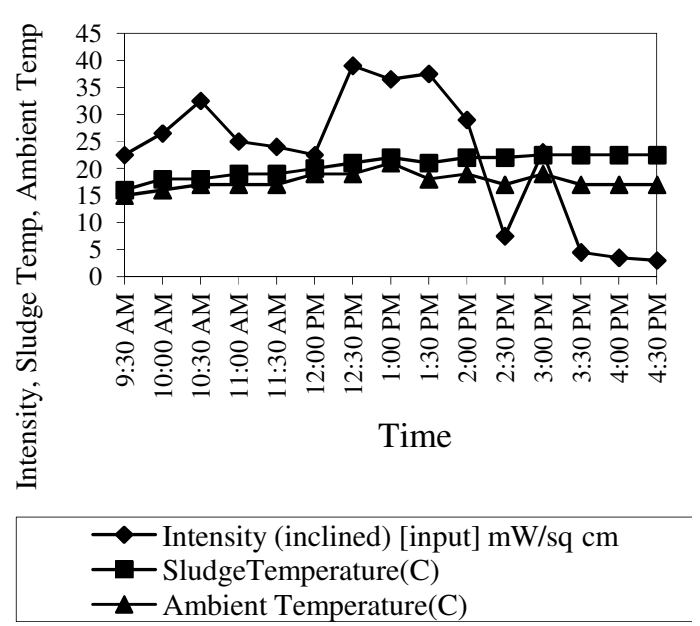

(b)

Fig. 5: Solar irradiance $\left(\mathrm{mW} / \mathrm{cm}^{2}\right)$, ambient temperature $\left({ }^{\circ} \mathrm{C}\right)$ and slurry temperature $\left({ }^{\circ} \mathrm{C}\right)$ Vs Time for one day in October, 2009 (a) and March, 2010 (b).

\section{METHOD OF ENERGY CALCULATION}

As stated earlier, the optimal temperature for psychrophilic, mesophilic and thermophilic bacteria growth, activity and biogas production is approximately $20^{\circ} \mathrm{C}, 35^{\circ} \mathrm{C}$ and $55^{\circ} \mathrm{C}$ respectively [8]. It is assumed that due to heating of the slurry by solar energy, the average temperature inside the methane tank is in near the optimal domain. Daily produced biogas amount, and electric power that may be obtained from this biogas is calculated as follows:

The volume of fluid $V_{f}=0.7 V_{d}=0.56 \mathrm{~m}^{3}\left(V_{d}=0.8 \mathrm{~m}^{3}\right.$ is volume of methane tank).

The mass of dry input $m_{o}$ is [6] calculated as;

$m_{o}=V_{f} \cdot \rho_{m}=28 \mathrm{~kg}$

Considering $\rho_{m} \sim 50 \mathrm{~kg} \mathrm{~m}^{-3}[6]$

The biogas volume calculated,

$V_{b}=c m_{o}=8.4 \mathrm{~m}^{3}$

$c$ is the biogas yield per unit dry mass $\left(0.2\right.$ to $\left.0.4 \mathrm{~m}^{3} \mathrm{~kg}^{-1}\right)$

The energy of biogas $E$ is calculated from [8] is;

$$
E=\eta H_{m} f_{m} V_{b}
$$

where $\eta$ is combustion efficiency $(60 \%), H_{m}$ is a heat of combustion $\left(20 \mathrm{MJm}^{-3}\right.$ at 0.01 atmosphere $), f_{m}$ is fraction of methane in biogas $(\sim 0.7)$. We have obtained $E=$ $70.6 \mathrm{MJ}$.

Assuming retention time $t_{r}=20$ days, daily energyproduced $E_{d e}$ by the biogas digester is calculated as;

$$
E_{d e}=\frac{E}{t_{r}}=3.5 \mathrm{MJ}=0.97 \mathrm{kWh}
$$


If this energy is used daily for two hours then the power $P_{e}$ of generator for conversion of biogas energy into electricity will be almost $0.48 \mathrm{~kW}$. The digester produces $0.4 \mathrm{~m}^{3}$ of biogasdaily.

Practically it was found that using sewage only and sewage with cow dung the retention times were 4 weeks and two weeks respectively, and the daily biogas produced were $0.2 \mathrm{~m}^{3}$ and $0.3 \mathrm{~m}^{3}$ respectively during one to two weeks without feeding by the slurry.

Before the use of the biogas in the generator it is desirable to upgrade it by water scrubbing [9] that increases the concentration of methane in biogas up-to $88-98 \%$. For this purpose a compressor of $100-200 \mathrm{~W}$ is needed for pumping of biogas through an absorption tower. For the production of electric power, generators fueled by natural gas, can be used.

\section{BIOGAS UPGRADING AND UTILIZATION}

To use biogas directly is simple and cheap, but it is acceptable mostly for heating and cooking if concentration of $\mathrm{H}_{2} \mathrm{~S}$ is sufficiently low. The biogas pressure in this case should be around of 8-25 mbar. To avoid corrosion due to the presence of $\mathrm{H}_{2} \mathrm{~S}$, it is recommended to use chimneys made from stainless steel or high temperature resistant plastic. It is recommended to remove water vapor from raw biogas. In this process $\mathrm{H}_{2} \mathrm{~S}$ is also removed partly. In the case of use of biogas as a vehicle fuel or natural gas in the present grid the quality of biogas should be improved or upgraded [9]. For this the concentration of methane be increased and carbon dioxide, $\mathrm{H}_{2} \mathrm{~S}$, water, particles etc. be removed. Upgraded biogas will have a higher calorific value, constant gas quality, does not have mechanical particles, and does not bring to corrosion and ice-clogging due to the presence of water. Table 1 shows the requirements to remove gaseous components depending on the biogas utilization.

Combined heat and power engine (CHP) may be an internal combustion engine, a spark ignition engine or a diesel engine. In the last case it will work as a dual fuel engine. Efficiencies of these engines are 29\% (for spark engine) and $31 \%$ (for diesel engine). One of the good applications of biogas is in the gas turbines for electric power generation, but the efficiency of turbines is sufficiently high at greater powers of around of $800 \mathrm{~kW}$. Table 1 show that the up gradation of biogas is important first of all for its use as the vehicle fuel and as a natural gas for the grid.

Table 1: Requirements to remove gaseous components depending on the biogas utilization.

\begin{tabular}{|l|c|c|c|}
\hline \multicolumn{1}{|c|}{ Application } & $\mathbf{H}_{\mathbf{2}} \mathbf{S}$ & $\mathbf{C O}_{\mathbf{2}}$ & $\mathbf{H}_{\mathbf{2}} \mathbf{O}$ \\
\hline Gas heater (boiler) & $<1 \mathrm{ppm}$ & No & No \\
\hline Kitchen stove & Yes & No & No \\
\hline $\begin{array}{l}\text { Stationary engine } \\
\text { (Combined heat and power engine) }\end{array}$ & $<1 \mathrm{ppm}$ & No & No Consideration \\
\hline Vehicle fuel & Yes & Recommended & Yes \\
\hline Natural gas grid & Yes & Yes & Yes \\
\hline
\end{tabular}

For carbon dioxide removal several methods such as water absorption, polyethylene glycol absorption, carbon molecular sieves and membrane separation were developed. Water scrubbing is simplest and cheap, and is used to remove $\mathrm{CO}_{2}$ and $\mathrm{H}_{2} \mathrm{~S}$ from biogas 
because these gases are soluble in water more than $\mathrm{CH}_{4}$. Figure 6 shows the removal of carbon dioxide and/or hydrogen sulphide from biogas and then its compression. The absorption is a physical process. The absorption tower is one of the important parts of the water scrubbing technology. Biogas under pressure is fed from the bottom of the tower whereas; water under pressure is fed from the top of the tower. The used water is regenerated in desorption tower by de-pressurizing or by stripping with air. An economical method is to use water without its recirculation and for this for example; water from a sewage treatment plant is available. As depicted in Fig. 5, the rectified biogas is used for the generation of electric power that in turn is used to feed compressors, pumps and any other load. Extra gas is compressed and bottled for use in vehicles, generators, etc.

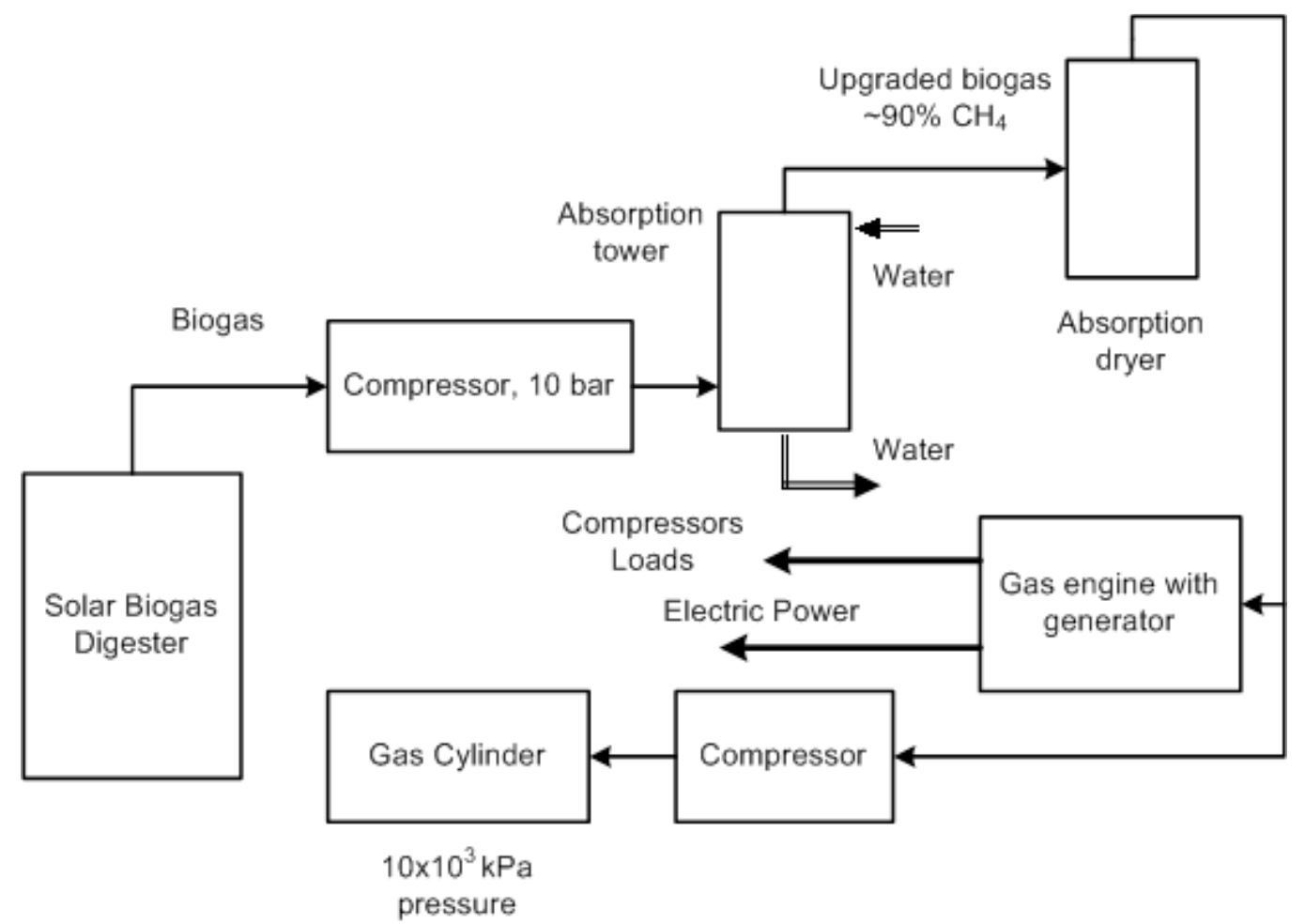

Fig. 6: Removal of carbon dioxide, hydrogen sulphide and water from biogas and conversion of its energy into electric power and compression.

Polyethylene glycol (PG) may be used for scrubbing; such as for water because it dissolves $\mathrm{CO}_{2}$ and $\mathrm{H}_{2} \mathrm{~S}$ better than water. Compared o water, using Polyethylene glycol the demand for the amount of solvent is less. In the case of (PG) absorption process, recirculation is used.

Micro-range porous, molecular sieve can be produced from coke [3]. Molecular sieves separate selectively some gases from the mixture of gases. The different mesh sizes and/or different applied pressure provide the selectivity properties under absorption process; such as if the pressure is decreases the absorbed gas is desorbed.

Membranes are used for gas separations under high and low pressure systems. In the case of high pressure systems the gas under a pressure of $36 \mathrm{bar}$ is cleaned by activated carbon to remove halogenated hydrocarbons, hydrogen sulphide and oil vapor from compressors. After this, gas passes through a particle filter and a heater. The acetatecellulose is used for the fabrication of membranes. The membranes separate small polar molecules as $\mathrm{CO}_{2}, \mathrm{H}_{2} \mathrm{O}$ and $\mathrm{H}_{2} \mathrm{~S}$, but cannot separate nitrogen from biogas. For low 
pressure system (pressure is 1bar); gas-liquid absorption membranes were developed recently: micro porous hydrophobic membrane separates the gaseous phase from the liquid phase. The biogas molecules from the gas phase side flows through the membrane to the liquid side that in turn flow in the direction of membrane's plane and are absorbed. Coral or $\mathrm{NaOH}$ are used as absorbent. This system is cost effective and efficient from the point of removal of $\mathrm{CO}_{2}$ and $\mathrm{H}_{2} \mathrm{~S}$. As $\mathrm{H}_{2} \mathrm{~S}$ is a very reactive substance, the removal of it is an important task and a number of methods are developed including; air/oxygen or iron chloride addition to biogas or slurry, use of iron sponge, iron oxide pellets, activated carbon, water scrubbing, $\mathrm{NaOH}$ scrubbing, biological removal on filter bed, air stripping and recovery. Table 2 shows biogas upgrading and utilization in some European countries and USA. From Table 2, it is seen that water scrubbing is the most popular method for the removal of $\mathrm{CO}_{2}$ and $\mathrm{H}_{2} \mathrm{~S}$ from biogas. Concerning utilization of biogas, it is mostly used as vehicle fuel.

Water removal is realized by: (i) condensation method, (ii) drying method and (iii) absorption of the gas to silica. The condensation method simply can be realized by using water taps in the gas pipe. Usually the water removal by this method is sufficient for gas that be used in the engine. In the drying method the biogas should be cooled resulting $t$ entrapment of water in the demister. The absorption dryer allows achieving high level of water removal from biogas. For these purpose two columns filled by silica is used in sequence: one column is connected to biogas pipeline system for drying of the biogas, the second column is regenerated by heating in opened conditions.

During experimental work that was done in the autumn and spring the slurry's temperature didn't exceed $40^{\circ} \mathrm{C}$. As in summer time the slurry's temperature can be more than $50^{\circ} \mathrm{C}$, therefore a "smart window" is designed for glass cover of the reflecting mirror based on the Venetian blind regulated by temperature control system, firstly and secondly, thermochromic coating based on vanadium oxide. These measures allow providing effective temperature dependent controlled shading of the reflecting mirror.

Table 2: Biogas upgrading and utilization in Europe and USA.

\begin{tabular}{|c|c|c|c|c|c|c|}
\hline Country & $\begin{array}{c}\text { Biogas } \\
\text { Utilization }\end{array}$ & $\begin{array}{c}\text { Biogas } \\
\text { production }\end{array}$ & $\begin{array}{c}\mathrm{CH}_{4} \\
\text { Reqd } \\
(\%) \\
\end{array}$ & $\begin{array}{c}\mathrm{CO}_{2} \text { Removal } \\
\text { technique }\end{array}$ & $\begin{array}{c}\mathrm{H}_{2} \mathrm{~S} \\
\text { Removal } \\
\text { technique } \\
\end{array}$ & $\begin{array}{c}\text { In } \\
\begin{array}{c}\text { Operation } \\
\text { since }\end{array} \\
\end{array}$ \\
\hline Czech.Rep. & Vehicle fuel & $\begin{array}{c}\text { Sewage; } \\
\text { sludge }\end{array}$ & 95 & Water scrubbing & $\begin{array}{c}\text { Water } \\
\text { scrubbing }\end{array}$ & 1985 \\
\hline France & Vehicle fuel & $\begin{array}{c}\text { Sewage; } \\
\text { sludge }\end{array}$ & 96.7 & Water scrubbing & $\begin{array}{c}\text { Water } \\
\text { scrubbing }\end{array}$ & 1994 \\
\hline Netherlands & Natural gas & $\begin{array}{l}\text { Landfill; green } \\
\text { waste }\end{array}$ & 88 & $\begin{array}{c}\text { Membranes; } \\
\text { carbon molecular } \\
\text { sieves }\end{array}$ & $\begin{array}{l}\text { Activated } \\
\text { Carbon }\end{array}$ & 1991 \\
\hline Sweden & Vehicle fuel & $\begin{array}{l}\text { Sewage } \\
\text { sludge; } \\
\text { vegetable } \\
\text { waste }\end{array}$ & 97 & $\begin{array}{l}\text { Water scrubbing; } \\
\text { carbon molecular } \\
\text { sieves }\end{array}$ & $\begin{array}{c}\text { Water } \\
\text { scrubbing; } \\
\text { Activated } \\
\text { Carbon }\end{array}$ & 1992 \\
\hline Switzerland & $\begin{array}{c}\text { Vehicle fuel, } \\
\text { natural gas }\end{array}$ & Bio waste & 96 & $\begin{array}{c}\text { Selexol scrubbing; } \\
\text { Membranes; water } \\
\text { scrubbing }\end{array}$ & $\begin{array}{c}\text { Selexol } \\
\text { scrubbing; } \\
\text { Activated } \\
\text { Carbon }\end{array}$ & 1981 \\
\hline USA & $\begin{array}{c}\text { Vehicle fuel, } \\
\text { natural gas }\end{array}$ & $\begin{array}{c}\text { Landfill; } \\
\text { Sewage sludge }\end{array}$ & 98 & $\begin{array}{c}\text { Selexol scrubbing; } \\
\text { Membranes; water } \\
\text { scrubbing }\end{array}$ & $\begin{array}{l}\text { Selexol } \\
\text { scrubbing; } \\
\text { Activated } \\
\text { Carbon }\end{array}$ & 1981 \\
\hline
\end{tabular}


Table 2 shows the main applications of biogas. At the same time biogas energy can be converted into electric power and heat by fuel cells. The biogas output may be increased by increasing the number of units of the biogas digesters. This biogas digester may be used domestically as well as for demonstrative or teaching purposes. In addition based on the results achieved it can be used for the construction of larger volume digesters for use on farms, especially located in remote and mountain areas where the weather in the winter period is cold.

\section{CONCLUSIONS}

The design, fabrication and investigation of a biogas digester with simple solar heater (built-in solar reverse absorber heater) are presented where the reverse absorber heater is installed under the methane tank. For a maximum temperature of $50^{\circ} \mathrm{Cinside}$ of the methane tank, using energy balance equation for the case of a static mass of fluid being heated the thickness of thermo insulating material was determined. The temperature of the slurry-solar irradiance and ambient temperature relationships were investigated experimentally. The biogas up gradation scheme for removal of carbon dioxide, hydrogen sulphide and water vapor from biogas and conversion of biogas energy conversion into electric power are discussed.

\section{ACKNOWLEDGEMENT}

The authors thank the Pakistan Science Foundation and GIK Institute of Pakistan for the support of this work.

\section{REFERENCES}

[1] Alkhamis, T.M., El-Khazali, R., Kablan, M.M., Akhusein, M.A. "Heating of a Biogas ReactorUsing a Solar Energy System with Temperature Control Unit." Solar Energy. 69.3 (200): 239-247.

[2] Carr J.J. "Elements of electronic instrumentation and measurement." $3^{\text {rd }}$ Ed. New Jersey Prentice-Hall Inc, 1996.

[3] Ilyas, S. "A case study to borrle the biogas in cylinders as source of power for rural industries development in Pakistan." World Applied Science Journal 1, 2(2006): 127-130 2006.

[4] Karimov Kh. S., Abid M. "Biogas Digester with Buit-in Solar Collector." Proc. REWAS2008, Global Symposium on Recycling, Waste Treatment and Clean Technology, Mexico, 2008: 1803-1808.

[5] Karimov Kh.S., Abid M. "Potentialities of biogas technology." ISBN: 978-3-639-14806-0, VDMVerlag Dr. Muller, Germany: 2009.

[6] Karimov Kh. S., Dikambaev Sh. B., Abid M., Turudbekov S.K., Bogombaev E.S., Vedenev A.G. "Production and utilization of biogas." ISBN 978-9967432-29-1. Avangard, Bishkek: 2009.

[7] Krepis I.B. "Sun for men.” 1989.

[8] Krepis I.B. "Potentialities of biogas production." News of Academy of Sciences of USSR, No. 1.Russian: (1979): 103-112.

[9] Tiwari, G. N. "Solar Energy Fundamentals, Design, Modeling and Applications". New Delhi, India: Narosa Publishing House, 2002.

[10] Twidell J. and Weir T. "Renewable energy resources." Printed in Great Britain at the Univesity Press, Cambridge, 1986.

[11] Parkin, I.P., Binions, R., Piccirillo, C., Blackman, C.S. and Manning, T.D. “Thermochromic coatings for intelligent architectural glazing”. Journal of Nano research, 2(2008):1-20. 
[12] Shirage, P.M., Sankpal, S.K. and Pawar, S.H. "Hiogas plants for fuel cell applications".Asvances in Renewable Energy Technologies, New Delihi, India, Narosa Publishing House (2003): 269-293.

[13] Walunj, B.E., and Pawar, S.H. "Role of catalyst for improvement of biogas quality". Advances in Renewable Energy Technologies, New Delhi, India: Narosa Publishing House 2003: 234242. 